\title{
Seed germination and seedling growth of two Pseudobombax species (Malvaceae) with contrasting habitats from Brazilian Cerrado
}

\author{
Clesnan Mendes-Rodrigues, Paulo Eugênio Oliveira \& Marli Aparecida Ranal \\ Programa de Pós-graduação em Ecologia e Conservação de Recursos Naturais, Instituto de Biologia, Universidade \\ Federal de Uberlândia, Caixa Postal 593, 38400-902 Uberlândia, Minas Gerais, Brazil; clesnan@ hotmail.com, \\ poliveira@ufu.br,ranal@ufu.br
}

Received 22-XI-2010. Corrected 07-IV-2011. Accepted 09-V-2011.

\begin{abstract}
Pseudobombax tomentosum and P. longiflorum are common trees in the Cerrado region, but the former species is more common in forest edges while the later is present in open cerrado areas. This work aimed to investigate differences in seed germination and seedling growth in these species, from seed collected from Cerrado areas in Central Brazil. For this, a seed germination experiment was designed and included four replicates with 25 seeds per species; seeds were randomly distributed in the germination chamber. To evaluate initial seedling growth, seedlings height was measured up to 67 days after seedling emergence; besides, some of these seedlings were grown for biomass evaluation during nine months. Results showed that seeds of the two species had the same germinability (near 100\%) and mean germination time (ca. 12 days). However, $P$. longiflorum showed a more spread seed germination through time, with higher values of coefficient of variation in germination time and uncertainty index; and lower values of synchronization than P. tomentosum. The two species showed basically the same growth pattern, but lower values for height of apical meristem, diameter of underground structures (mostly roots), dry mass of shoots, underground structure and total mass of seedlings in P. tomentosum were obtained, compared to P. longiflorum. Both species allocated more dry mass to underground structures in detriment of shoot. This probably allows resprouting behavior which prevents hydric stress and detrimental fire action typical of the open Cerrado areas. Rev. Biol. Trop. 59 (4): 1915-1925. Epub 2011 December 01 .
\end{abstract}

Key words: Cerrado, seed germination measurements, Neotropical savannas, plant growth, seedling growth, Pseudobombax longiflorum, Pseudobombax tomentosum.

Seed germination patterns differ in the same family, genus and even for the same species (Baskin \& Baskin 1998). Inside the Bombacaceae, now the subfamily Bombacoideae, Malvaceae sensu lato (APG 2003), there are species with dormant and non-dormant seeds (Vazquez-Yanes 1974, Joly \& Crawford 1983, Danthu et al. 1995), but information about seed germination patterns is not available yet for most taxa of this group.

Germination within the large Neotropical genus Pseudobombax is still poorly studied and the few published works are restricted to the germinability assessment, and sometimes to the speed of the process, based on the first and the last seed germinated in experimental conditions (Souza \& Válio 2001, Souza-Silva et al. 2001, Zamith \& Scarano 2004, Wittmann et al. 2007, Lopes et al. 2008). Other studies for the family focused on the ratio between dry mass of roots and shoots or on seedling growing under different light and soil conditions, without records for Pseudobombax (Moreira \& Klink 2000, Scalon et al. 2003).

Among the species of Bombacoideae from cerrado, $P$. longiflorum and $P$. tomentosum are species that occur in open fire-prone plant formations, but also at the edge or inside gallery, deciduous and mesophyllous forests (Gribel 1988, Silva \& Scariot 2004). P. longiflorum is 
much more common in open savanna formations and has hanging bat pollinated flowers (Coelho \& Marinho Filho 2002). P. tomentosum is much more common in forest habitats where its sturdy flowers depend on non-flying mammals passing from crown to crown for pollination (Gribel 1988). Except from the differences in habitat, the species are similar in relation to the distribution, phenology and seed dispersion period (Lorenzi 1992, Silva Júnior et al. 2005). The absence of exclusive habitats between the two species reflect the presence of physiognomic gradients and transitions among savanna and forest areas in the Cerrado Biome (Ribeiro \& Walter 1998). The water stress and the occurrence of seasonal fire in the Cerrado biome select species with ability to resprout after these events, leading to the allocation of available resources to the roots or other underground structures in detriment of the shoots in open formation species while forest species show allocation to aerial parts in detriment of the roots (Hoffmann \& Franco 2003). Inside mesophyllous forest and gallery forest formations, light is the limiting factor but habitat shows less oscillations in water regime and temperature, favoring fast and synchronized seed germination whenever gaps or leaf fall cycles improve seedling survival chances as discussed by Garwood (1983). Meanwhile, in the savanna habitats, the limiting factors are water and nutrients, and seed germination spread in time, and even dormancy, may favor seedling survival (Moreira \& Klink 2000, Hoffmann \& Franco 2003, Oliveira 2008, Vieira et al. 2008).

In this context, vicariant species as the ones studied here provide the opportunity to see how habitat specialization would be reflected in germination and seedling growth (Hoffmann \& Franco 2003). The objective of this paper was to test, on the one hand, if seed germination of $P$. longiflorum would be more asynchronous and seedling mass allocated predominantly in the underground structures, favoring seedling survival in the open savanna areas. On the other hand, for P. tomentosum, typical of forest formation with less water stress, with an expected more synchronized germination process and seedlings would have more mass allocated to the stems, favoring light absorption and continuous growth.

\section{MATERIAL AND METHODS}

Studied species: Pseudobombax longiflorum (Mart. \& Zucc.) Robyns (Bombacoideae, Malvaceae) is found in most Cerrado areas. It is fairly common in Minas Gerais and down to the North of Paraná State. It is a deciduous tree, which occurs sparsely in open Cerrado areas (Lorenzi 1992). Flowering occurs from July to November and fruits mature during the next dry season, from July to November (Silva Júnior et al. 2005). P. tomentosum (Mart. \& Zucc.) Robyns (Bombacoideae, Malvaceae) is usually a larger tree, found in Cerradão (dense cerrado with almost closed woodland) and Cerrado (closed vegetation dominated by trees and shrubs with herbaceous vegetation between them), but mainly in the edges and sometimes inside mesophyllous and gallery forests. It occurs in most Cerrado region down to Southern areas of São Paulo and Mato Grosso do Sul. It flowers from July to August and the fruits mature from August to October. It is a deciduous and heliophyllous plant, also appearing less frequently in open vegetation, usually on sandy or humic clay soils, but also on better drained oxisoils common in the Cerrado region (Lorenzi 1992, P.E. Oliveira, pers. observ.). The voucher specimens can be found in Herbarium Uberlandense.

Studied area: About 200 seeds of both species were collected in the Cerrado areas, Neotropical savannas region in Central Brazil (sensu Ribeiro \& Walter 1998). The seeds of P. tomentosum were collected in forest areas, near to Uberlândia city, Minas Gerais state $\left(19^{\circ} 07^{\prime} \mathrm{W}-48^{\circ} 22^{\prime} \mathrm{S}\right)$ and the seeds of $P$. longiflorum were collected in adjacent open pasture and areas along the BR050 highway

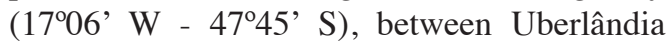
and Brasília. Germination and seedling growth experiments were carried out at the Campus 
of the Federal University of Uberlândia. The region climate is characterized as Aw according to the Köppen scale (Köppen 1948), tropical humid climate with a dry winter (April to September) and rainy summer (October to March) (Rosa et al. 1991).

Seed germination: Mature fruits of both species were collected in September and October 2003. The fruits were collected directly from the trees and placed to dry at room temperature in order to facilitate the extraction of the seeds. Seeds were stored in paper bags at room temperature (between 25 and $30^{\circ} \mathrm{C}$ ), in a dry chamber containing silica gel with humidity indicator, and kept until the installation of the experiment, 30 days later. The seeds were sown on fine vermiculite (expansion volume of $0.1 \mathrm{~m}^{3}$ ), inside transparent germination boxes, moistened as necessary with distilled water. Boxes were kept in a germination chamber (Seedburo Company, model MDG2000) under continuous light (mean $=11.90, \mathrm{SD}=6.52 \mu \mathrm{mol} /$ $\mathrm{m}^{2} / \mathrm{s}$ of photosynthetically active radiation), at $25^{\circ} \mathrm{C}$. The experimental units were randomly distributed in the germination chamber, four replicates for each species with 25 seeds per replicate. The seed sample size was somewhat limited as a consequence of the high level of predation of fruits and seeds during the collection year. Although seed samples used for the experiments were rather small, the data was still sufficient for consistent statistical tests.

The number of germinated seeds was observed daily and protrusion of the radicle or any part of the embryo was used as germination criterion. Germinability $(\mathrm{G})$, represented by the percentage of germination in the experimental conditions (Labouriau 1983), mean germination time (MGT) ( $\bar{t}$, Labouriau 1970), germination time to $50 \%$ germination (GT50), germination time of the first germinated seed (GTFS), germination time of the last germinated seed (GTLS), coefficient of variation of the germination time (CVGT) $\left(\mathrm{CV}_{\mathrm{t}}\right.$, Ranal \& Santana 2006), mean germination rate (MGR) ( $\bar{v}$, Labouriau 1970), uncertainty of germination (UG) (U, Labouriau \& Valadares 1976) and synchronization index of germination (ZG) (Z, Ranal \& Santana 2006 adapted from Primack 1980) were used to describe the germination process. Further details on mathematical expressions, authorship, intermediate calculus, the sense and the applications of these germination measurements can be found in Ranal \& Santana (2006) and Ranal et al . (2009). All germinated seeds were checked for the presence of more than one embryo per seed, known as polyembryony and common in Bombacoideae (Mendes-Rodrigues et al. 2005).

Seedling morphology and height: Seeds germinated in laboratory conditions were transplanted to black plastic bags $(30 \mathrm{~cm}$ high per $13 \mathrm{~cm}$ diameter), filled with previously sieved open Cerrado oxisol. Seedlings were kept in a greenhouse covered with black plastic net with 50\% shading and moistened when necessary. Starting from emergence date, periodic measurements of the maximum height of each plant, considered from ground to the apex of the last leaf were carried out (Fig. $1 \mathrm{H}-1$ ). The data were adjusted to a linear regression model, as a function of the days from emergence. Some 20 $P$. longiflorum seedlings were evaluated up to 67 days after emergence and 15 P. tomentosum seedlings up to 63 days after emergence, when initial growth appeared to stabilize (seedlings showed no further increment in height). The seedling functional morphology was classified based on Miquel (1987). These seedlings were kept for nine months under the same conditions to asses a biomass allocation evaluation, as described below.

Biomass allocation: Seedlings for biomass evaluation were analyzed nine months after sowing, before foliar abscission started. Seven plants of each species were removed from the soil and analyzed for the leaf number per plant, length of the shoot (considered from the soil to the apex of the last leaf) (Fig. 1 $\mathrm{H}-1$ ), height of the apical meristem (from soil to the apical meristem) (Fig. $1 \mathrm{H}-2$ ), height of insertion of the first leaf from soil (Fig. 1 $\mathrm{H}-3$ ), diameter at the shoot base, the largest 

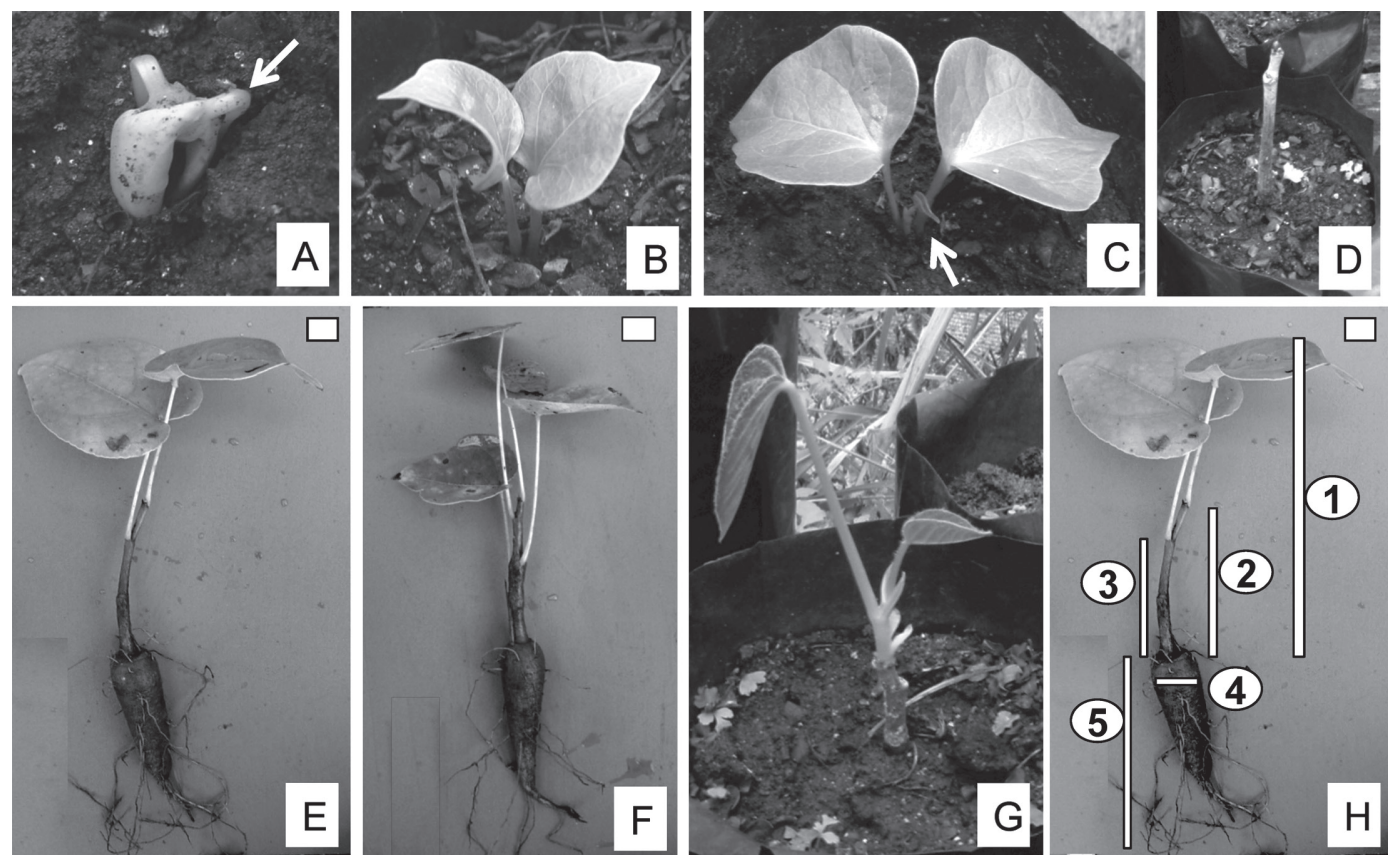

Fig. 1. Development phases of Pseudobombax seedlings, (A-E, G) Development phases of P. longiflorum. (F and $\mathbf{H})$ Development phases of P. tomentosum. (A) Epygeal seedling emergence due to petiole elongation (see the arrow). (B) Cotyledon leaves with both petioles. (C). Aerial part emission (see the arrow). (D) Seedling with about 9-10 months, without leaves. (E) Seedling with 9 months; see the massive underground structure. (F) Seedling with 9 months; see the massive underground structure. (G) Resprouting of a seedling about 12-18 months from the emergence. (H) Seedling measurements: 1. Plant height, 2. Apical meristem height, 3. Height of the insertion of the first leaf, 4. Underground structure diameter, 5. Underground structure length. Scale bars $=2 \mathrm{~cm}$.

diameter of the underground structure (Fig. 1 $\mathrm{H}-4)$ and the length of the underground structure (Fig. $1 \mathrm{H}-5)$. The seedlings were divided into aerial (stems and leaves) and underground parts (mostly roots), and dried to constant mass at $70^{\circ} \mathrm{C}$ (eight days). The dry mass ratio between underground and aerial parts and between underground and total seedling dry mass were calculated (Hunt 1990). Non-quantitative observations continued up to 18 months after sowing.

Germination measurements and seedling biometry data were evaluated for normality with the Shapiro-Wilk test. Data with normal distribution were compared using Student's $t$-test (all seedling biometry measurements, except underground structure length) and data without normal distribution were compared by Mann-Whitney test (all germination measurements, plus underground structure length). The relative frequency of seed germination was compared between species using the Kolmogorov-Smirnov test. The seedling height collected during the first 70 days was adjusted to a simple linear regression model as a function of the time from emergence and the significance of the model tested with ANOVA. The slope and intercept of the linear regression were compared between species using Student's $t$-test. For all the statistical analysis 0.05 of significance was adopted and procedures were based on Sokal \& Rolf (1995).

\section{RESULTS}

Seed germination: Seeds of $P$. longiflorum and $P$. tomentosum did not present 
significant differences in germinability, mean germination time and mean germination rate (Table 1). On the other hand, seeds of $P$. tomentosum presented greater homogeneity (lower value of CVGT) and higher synchrony of germination (lower value of UG and higher value of $\mathrm{ZG}$ ) than $P$. longiflorum. The first germination was registered for $P$. longiflorum four days after the beginning of the experiment and the last germination occurred after 20 days. For P. tomentosum germination started after seven days and continued up to the 18th day after sowing (Fig. 2). The distribution of the relative frequency of germination differs between species $(\mathrm{D}=0.1980$, $\mathrm{p}<0.05$ ) and demonstrated that in $P$. longiflorum, this process was more spread out through time, with some peaks of germination in days 11, 13, 14 and 16, while in P. tomentosum, germination was less spread out in time and a strong germination peak occurred at the 11th day after sowing (Fig. 2). After 20 days, the remaining seeds were already degenerating and no further germination occurred. The two species presented only one embryo per seed and no polyembryony was recorded.

TABLE 1

Mean germination measurements $( \pm \mathrm{SD})$ of P. longiflorum and P. tomentosum (Bombacoideae, Malvaceae) seeds

\begin{tabular}{ccccc} 
Measurement (unity) & P. longiflorum $^{1}$ & P. tomentosum & $\mathrm{U}^{2}$ & $\mathrm{p}^{3}$ \\
G (\%) & $99.00 \pm 2.00$ & $97.00 \pm 2.00$ & 4.00 & 0.2482 \\
MGT (day) & $12.17 \pm 0.32$ & $11.68 \pm 0.48$ & 4.30 & 0.1489 \\
GT50 (day) & $13.25 \pm 0.50$ & $13.25 \pm 0.50$ & 8.00 & 1.0000 \\
GTFS (day) & $4.50 \pm 1.00$ & $7.75 \pm 0.50$ & 0.00 & 0.0209 \\
GTLS (day) & $18.25 \pm 1.26$ & $16.75 \pm 0.96$ & 2.50 & 0.1124 \\
CVGT (\%) & $30.17 \pm 1.78$ & $22.25 \pm 4.83$ & 4.00 & 0.0209 \\
MGR (day ${ }^{-1}$ ) & $0.08 \pm 0.02$ & $0.09 \pm 0.003$ & 4.30 & 0.1489 \\
UG (bit) & $3.29 \pm 0.09$ & $2.81 \pm 0.24$ & 4.00 & 0.0209 \\
ZG & $0.08 \pm 0.004$ & $0.14 \pm 0.04$ & 4.00 & 0.0209 \\
\hline
\end{tabular}

1. $\mathrm{CVGT}=$ coefficient of variation of the germination time, $\mathrm{G}=$ germinability, $\mathrm{MGT}=$ mean germination time, $\mathrm{MGR}=\mathrm{mean}$ germination rate, GT50=germination time to $50 \%$ germination, GTFS=germination time of the first seed, GTLS=germination time of the last seed, $\mathrm{UG}=$ uncertainty of germination, $\mathrm{ZG}=$ synchronization index of germination.

2. $U=$ statistics of the Mann Whitney test.

3. $\mathrm{p}=$ probability.

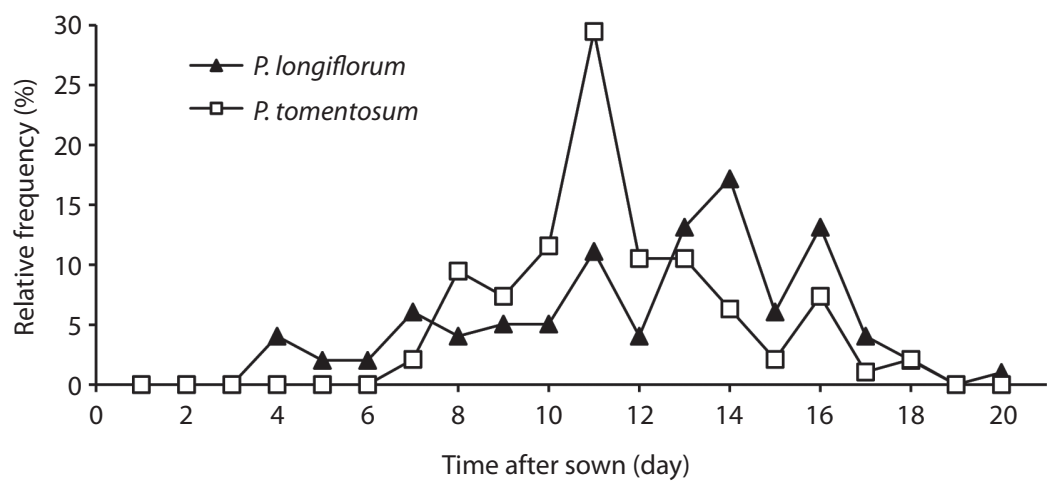

Fig. 2. Relative frequency (\%) of seed germination of two Pseudobombax species (Bombacoideae, Malvaceae). 
Seedling morphology and height: The seedlings of both species presented photosynthetically active cotyledons exposed above ground (Fig. 1 A-C) and were classified as phanero-epigeal-foliaceous (PEF sensu Miquel 1987). In classical PEF type the cotyledons are suspended from the ground by elongation of hypocotyl, while in these two species of Pseudobombax the elongation is caused by elongation of cotyledon petiole (Fig. 1 A). Although cotyledons are hold above ground, their fixation point remains below ground (Fig. 1 A-C). The seedling height of both species was well adjusted to a simple linear regression model $\left(\mathrm{r}^{2}=0.8091, \mathrm{~F}_{1,105}=445.02\right.$, $\mathrm{p}<0.0001$ for $P$. longiflorum and $\mathrm{r}^{2}=0.8087$, $\mathrm{F}_{1.105}=393.21, \mathrm{p}<0.0001$ for $P$. tomentosum) (Fig. 3A, 3B). The two species showed no significant differences between the slopes of the equation ( $t=0.136$, d.f. $=198, \mathrm{p}>0.05)$, nor between intercepts $(\mathrm{t}=0.832$, d.f. $=199, \mathrm{p}>0.05)$, presenting basically the same pattern of continuous growth during the first 70 days.

Biomass allocation of dry mass: Both species presented an underground structure (mostly roots) which represented about $80 \%$ of the total mass of seedlings (Fig. 1 E-F). Among the analyzed characteristics, the height of the apical meristem, diameter and the dry mass of underground structure, shoot and whole seedling dry mass were statistically higher in P. longiflorum in comparison with P. tomentosum (Table 2). For the other characteristics there were no significant differences. Both species cessed growth between 10 and 12 months, followed by leaf loss and resprout after the cool dry period (Fig. $1 \mathrm{D}-\mathrm{G}$ ).
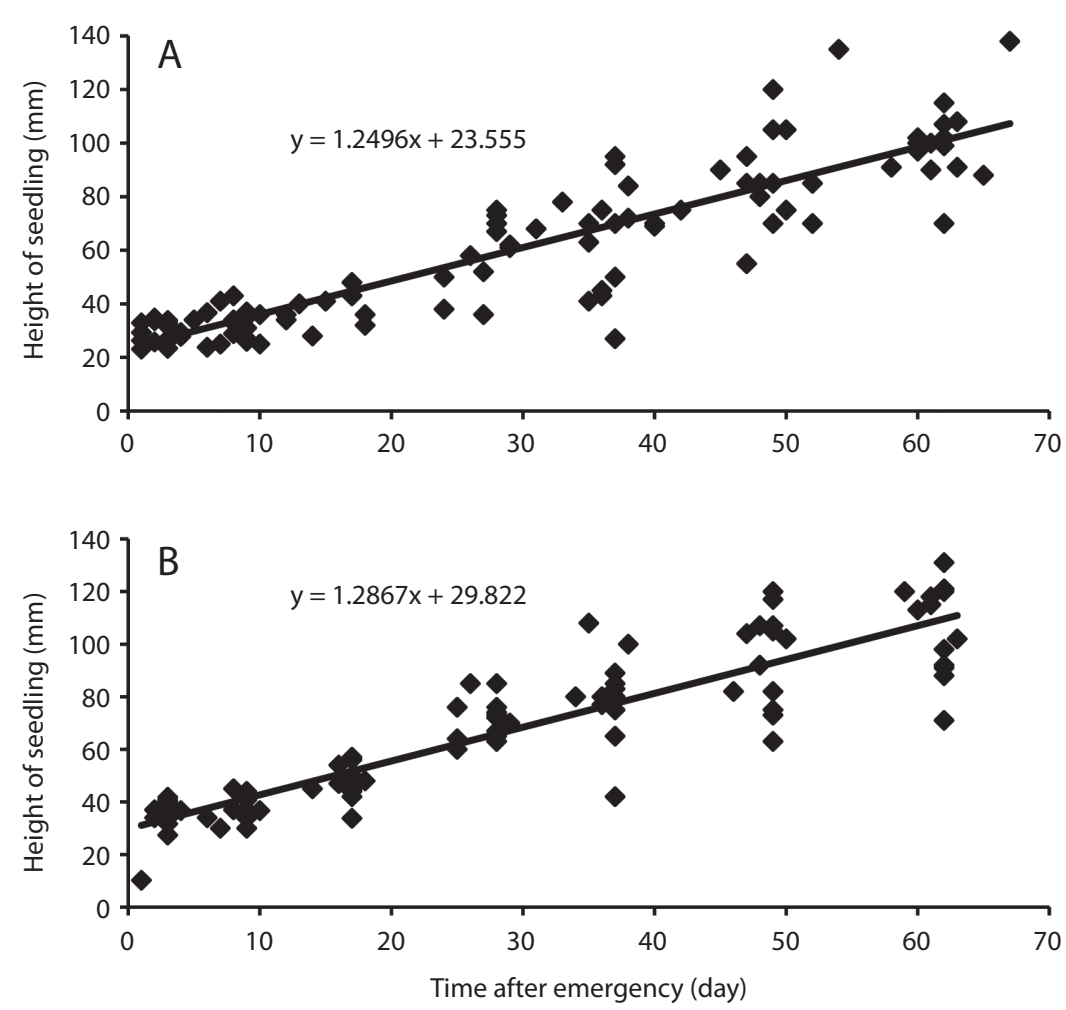

Fig. 3. Growth in height of two Pseudobombax species (Bombacoideae, Malvaceae) seedlings cultivated under 50\% shading in Uberlândia, Minas Gerais state, Brazil. (A) P. longiflorum. (B) P. tomentosum. 
TABLE 2

Mean of biometry and allocation of dry matter in seedlings $( \pm \mathrm{SD})$ of P. longiflorum and P. tomentosum (Bombacoideae, Malvaceae), cultivated by nine months under $50 \%$ of natural light in Uberlândia, Minas Gerais state, Brazil

\begin{tabular}{lcccc}
\multicolumn{1}{c}{ Measurement (unity) } & P. longiflorum & P. tomentosum & Statistics $^{1}$ & $\mathrm{p}^{2}$ \\
Number of leaves & $4.00 \pm 0.67$ & $4.28 \pm 0.90$ & $\mathrm{t}=0.60$ & 0.5577 \\
Seedling height (mm) & $128.29 \pm 13.41$ & $118.30 \pm 17.79$ & $\mathrm{t}=1.19$ & 0.2585 \\
Apical meristem height (mm) & $59.07 \pm 9.33$ & $41.06 \pm 8.49$ & $\mathrm{t}=3.78$ & 0.0026 \\
Shoot diameter (mm) & $6.56 \pm 0.98$ & $6.94 \pm 1.27$ & $\mathrm{t}=0.63$ & 0.5373 \\
Underground structure length (mm) & $113.95 \pm 18.23$ & $109.19 \pm 13.51$ & $\mathrm{U}=29.00$ & 0.6200 \\
Underground structure diameter (mm) & $24.54 \pm 1.14$ & $20.60 \pm 1.33$ & $\mathrm{t}=5.96$ & 0.0001 \\
Height of the first leaf insertion (mm) & $29.30 \pm 11.44$ & $23.07 \pm 6.98$ & $\mathrm{t}=1.23$ & 0.2425 \\
Aerial dry mass (mg) & $1179.76 \pm 156.52$ & $981.67 \pm 181.15$ & $\mathrm{t}=2.19$ & 0.0490 \\
Underground dry mass (mg) & $6145.10 \pm 277.16$ & $4310.81 \pm 1142.06$ & $\mathrm{t}=4.13$ & 0.0061 \\
Seedling dry mass (mg) & $7324.86 \pm 331.90$ & $5292.48 \pm 1200.35$ & $\mathrm{t}=4.32$ & 0.0050 \\
Underground/aerial dry mass ratio & $5.09 \pm 0.64$ & $4.27 \pm 1.06$ & $\mathrm{t}=1.76$ & 0.1030 \\
Aerial/seedling mass ratio & $0.16 \pm 0.02$ & $0.20 \pm 0.001$ & $\mathrm{t}=1.98$ & 0.0707 \\
\hline
\end{tabular}

1. $t=$ statistics of the $t$ "Student" test, $U=$ statistics of the Mann Whitney test.

2. $\mathrm{p}=$ probability.

\section{DISCUSSION}

Both species of Pseudobombax presented high germinability and similar growth patterns, but there were some differences in germination time and synchrony, which may be associated to their preferential habitat. The high germinability of the seeds of both Pseudobombax studied species is similar to the one observed in other Bombacoideae (Melo et al. 1979, SousaSilva et al. 2001, Scalon et al. 2003, Zamith \& Scarano 2004, Fanti \& Perez 2005, Maia et al. 2005, Wittmann et al. 2007, Lopes et al. 2008, Zamora-Cornelio et al. 2010), and contrast with lower germinability recorded for other species of Pseudobombax (Sánchez \& Zepeda 2004, Sautu et al. 2006). This also indicates the absence of marked dormancy in Pseudobombax, although species with mechanical dormancy occur in Bombacoideae (Danthu et al. 1995, Barbosa et al. 2004, Pinto et al. 2004).

The germination process of both species was relatively slower; with mean germination times higher than the 5.1 to 7.1 days recorded for other Bombacoideae (Souza \& Válio 2001, Ranal et al. 2010), but was similar to seedling emergence times described for the group
(Mendes-Rodrigues et al. 2005). The germination time to $50 \%$ of germination (GT50) was also higher than the 5 to 7 days recorded for other species in the group (Maia et al. 2005, Zamora-Cornelio et al. 2010).

The duration of germination process was distributed along 4.50 to 18.25 days in the studied species (Germination time of the first seedGTFS and of the last seed-GTLS), which is inside the ample variation recorded for species in the group, which ranged from 3 (ZamoraCornelio et al. 2010) to 19 days (Sautu et al. 2006) to GTFS and from 6 (Zamora-Cornelio et al. 2010) to 284 days (Sautu et al. 2006) to GTLS.

The gradual germination process for both studied species of Pseudobombax can be considered a type of relative dormancy (sensu Labouriau 1983). It is not a mechanical dormancy as observed for Ochroma pyramidale (Cav. ex Lam.) Urb. (Zamora-Cornelio et al. 2010), but it results in a germination process spread through time in opposition to a single germination peak observed in e.g. Ceiba speciosa (A.St.-Hil., A.Juss. \& Cambess.) Ravenna (Ranal et al. 2010). This strategy of spreading the germination through time is present in 
other species occurring in the Cerrado region (Carvalho et al. 2005, Pereira et al. 2009, Ranal et al. 2010, Mendes-Rodrigues et al. 2010).

P. tomentosum showed significantly higher synchronization of germination than that observed for P. longiflorum seeds. The more asynchronous and heterogeneous germination observed for $P$. longiflorum seeds would increase survival ability at the beginning of the rains, which may vary in intensity and frequency in the Cerrado region (Oliveira 2008).

The seedlings of the two species of Pseudobombax differed from others species within the subfamily as Bombacopsis glabra (Pasq.) A. Robyns (Baker 1960) and Eriotheca pubescens Schott \& Endl. (Mendes-Rodrigues et al. 2005) which are polyembrionic. The functional morphology type of seedlings of $P$. longiflorum and $P$. tomentosum differed from P. ellipticum (Kunth) Dugand and P. munguba (Mart. \& Zucc.) Dugand, which present the cotyledons suspended by hypocotyl elongation (Sánchez \& Zepeda 2004, Maia et al. 2005), a pattern commonly observed in classical PEF type (Ressel et al. 2004).

$P$. longiflorum and P. tomentosum presented similar growth pattern during the first 70 days. This trend of linear initial growth has been also observed for other Bombacoideae such as Ceiba pentandra (L.) Gaertn. (Pedroso \& Varela 1995) and B. glabra (Scalon et al. 2003). The leaf fall and resprout after the cooler part of the dry season were not previously recorded for Pseudobombax, but this brevideciduous leafing behavior is common among seedlings of other Cerrado species (Oliveira \& Silva 1993, Oliveira 2008).

Larger seedlings observed in $P$. longiflorum in relation to $P$. tomentosum could also be viewed as a way to increase chances of survival, since open Cerrado plants have a limited growing season (Oliveira 2008). Nevertheless, both species presented seasonal growth and dry matter allocation ratios similar to other Cerrado trees (Oliveira \& Silva 1993, Moreira \& Klink 2000). Despite their difference in predominant habitat, the two species of Pseudobombax allocated most dry mass to underground structures in detriment of the shoots. This root biased allocation would allow greater resistance to water and temperature stress during the dry period in open Cerrado plant formations, but would hinder competition and growth in forest environments (Hoffmann \& Franco 2003, Vieira et al. 2008). The preferential investment to underground structures has been also recorded for other species from open Cerrado formations (Moreira \& Klink 2000, Hoffmann \& Franco 2003), including some species of Bombacoideae (Moreira \& Klink 2000, Ronquim et al. 2003, Ressel et al. 2004). But even for vicariant pairs of species restricted to either the savanna or forest, the physiological and developmental features were not easy to contrast (Hoffmann \& Franco 2003). It is important to notice here that the differences in seedling size may be a result of a better adjustment of $P$. longiflorum seeds to the Cerrado soil used in the experiment.

Although the two Pseudobombax species differ in synchrony of germination and in some aspects of growth pattern, those differences are not clearcut and may be explained by the distribution overlap between species. New and more refined experiments will be necessary to see whether these differences, despite being significant, would really favour habitat specialization in the studied species.

\section{ACKNOWLEDGMENTS}

Thanks to Conselho Nacional de Desenvolvimento Científico e Tecnológico - CNPq, and Fundação de Amparo à Pesquisa do Estado de Minas Gerais - FAPEMIG for the research grant to the first author and the Denise Garcia de Santana for help in some of the statistical analysis. To Glauco Machado and Felipe Wanderley Amorim for the reading of the first versions of the manuscript and to Francielle Paulina de Araújo for the revision of the resumen. The results are part of the MSc. dissertation of the first author in the PostGraduate Program of Ecology and Conservation of Natural Resources - Universidade Federal de Uberlândia. 


\section{RESUMEN}

Pseudobombax tomentosum y $P$. longiflorum son árboles comunes en la región del Cerrado, pero la primera especie es más común en los bordes del bosque mientras que el segundo está presente en áreas abiertas del cerrado. Este trabajo tuvo como objetivo investigar las diferencias en la germinación de las semillas y el crecimiento de ambas especies. Los individuos fueron recolectados en áreas del Cerrado, la región de savanas neotropicales en el centro de Brasil. Fueron utilizados para cada especie cuatro repeticiones con 25 semillas cada una para el experimento de germinación, distribuidas al azar en la cámara de germinación a $25^{\circ} \mathrm{C}$. Las plántulas fueron evaluadas en cuanto al crecimiento inicial hasta 67 días después de la emergencia de la plántula. Algunas plantas se mantuvieron para la evaluación de la biomasa durante nueve meses, y luego se mideron para evaluar diferencias en el crecimiento y distribución de masas entre especies. Ambas presentaron la misma capacidad germinativa (cerca de 100\%) y tiempo medio de germinación (alrededor de 12 días). Sin embargo, $P$. longiflorum presentó una germinación más dispersa en el tiempo, con valores más altos de coeficiente de variación de tiempo de germinación y el índice de incertidumbre, y valores más bajos de la sincronización que $P$. tomentosum. Las dos especies demostraron básicamente el mismo patrón de crecimiento, pero $P$. tomentosum presentó valores más pequeños en la altura del meristemo apical, diámetro de las estructuras subterráneas (sobre todo las raíces), masa seca de la estructura aérea, estructura subterránea y plántulas en comparación con P. longiflorum. Ambas especies asimilaron más masa seca en las estructuras subterráneas en detrimento de las aéreas. Esto probablemente permite una conducta de rebrote que evita el estrés hídrico y la acción perjudicial de incendios típicos de las zonas del cerrado abierto.

Palabras clave: Bombacoideae, Cerrado, germinación de semillas, savanas neotropicales, crecimiento de las plantas, Pseudobombax tomentosum, Pseudobombax longiflorum.

\section{REFERENCES}

APG. 2003. An update of the Angiosperm Phylogeny Group classification for the orders and families of flowering plants: APG II. Bot. J. Linn. Soc. 141: 399-436.

Baker, H.G. 1960. Apomixis and polyembryony in Pachira oleaginea (Bombacaceae). Amer. J. Bot. 47: 296-302.

Barbosa, A.P., P.T.B. Sampaio, M.A.A. Campos, V.P. Varela, C.Q.B. Gonçalves \& S. Iida. 2004. Alternative technology for breaking dormancy of balsa wood (Ochroma lagopus Sw., Bombacaceae) seeds. Acta Amazonica 34: 107-110 (also available on-line: www.scielo.br/pdf/aa/v34n1/v34n1a13.pdf).
Baskin, C.C. \& J.M. Baskin. 1998. Seeds: ecology, biogeography, and evolution of dormancy and germination. Academic, San Diego, California, USA.

Carvalho, M.P., D.G. Santana \& M.A. Ranal. 2005. Anacardium humile A. St.-Hil. (Anacardiaceae) seedling emergence evaluated by means of small samples. Rev. Bras. Bot. 28: 627-633 (also available on-line: www.scielo.br/pdf/rbb/v28n3/29011.pdf).

Coelho, D.C. \& J. Marinho Filho. 2002. Diet and activity of Lonchophylla dekeyseri (Lonchophyllinae, Phyllostomidae) in the Federal District, Brazil. Mammalia 66: $319-330$

Danthu, P., J. Roussel, A. Gaye \& E.H.E. Mazzoudi. 1995. Baobab (Adansonia digitada L.) seed pretreatments for germination improvement. Seed Sci. Technol. 23: 469-475.

Fanti, S.C. \& S. Perez. 2005. Effects of accelerating aging on the seed vigor of Chorisia speciosa St. Hil. - Bombacaceae. R. Árvore 29: 345-352 (also available on-line: http://www.scielo.br/pdf/rarv/v29n3/a01v29n3.pdf).

Garwood, N.C. 1983. Seed germination in a seasonal tropical forest in Panama: A community study. Ecol. Monogr. 53: 159-181.

Gribel, R. 1988. Visitis of Caluromys lanatus (Didelphidae) to flowers of Pseudobombax tometosum (Bombacaceae): A probable case of pollination by marsupials in Central Brazil. Biotropica 20: 344-347.

Hoffmann, W.A. \& A.C. Franco. 2003. Comparative growth analysis of tropical forest and savanna woody plants using phylogenetically independent contrasts. J. Eco. 91: 475-484.

Hunt, R. 1990. Basic growth analysis: Plant growth analysis for beginners. Unwin Hyman, London, United Kingdom.

Joly, C.A. \& R.M.M. Crawford. 1983. Germination and some aspects of the metabolism of Chorisia speciosa St. Hill. seeds under anoxia. Rev. Bras. Bot. 6: 85-90.

Köppen, W. 1948. Climatología: con un estudio de los climas de la Tierra. Fondo de Cultura Económica, México D.F., México.

Labouriau, L.G. 1970. On the physiology of seed germination in Vicia graminea Sm - I. An. Acad. Bras. Cienc. 42: 235-262.

Labouriau, L.G. 1983. A germinação das sementes. Organização dos Estados Americanos. Programa Regional de Desenvolvimento Científico e Técnologico. Série 
de Biologia. Monografia 24, Washington, Washington, USA.

Labouriau, L.G. \& M.E.B. Valadares. 1976. On the germination of seeds of Calotropis procera (Ait.) Ait.f. An. Acad. Bras. Cienc. 48: 263-284.

Lopes, J.C., M.T. Matheus, N.B. Corrêa \& D.P. Silva. 2008. Germinação de sementes de embiruçu (Pseudobombax grandiflorum (Cav.) A. Robyns) em diferentes estádios de maturação e substratos. Floresta 38: 331-337 (also available on-line: ojs.c3sl.ufpr.br/ ojs2/index.php/floresta/article/viewFile/11628/8162).

Lorenzi, H. 1992. Árvores brasileiras: manual de identificação e cultivo de plantas arbóreas nativas do Brasil. Plantarum, Nova Odessa, São Paulo, Brasil.

Maia, L.A., S. Maia \& P. Parolin. 2005. Seedling morphology of non-pioneer trees in Central Amazonian várzea floodplain forests. Ecotropica 11: 1-8 (also available on-line: www.gtoe.de/public_html/publications/pdf/11\%201/Maia,\%20Maia\%20\&\%20Parolin,\%202005.pdf).

Melo, J.T., J.F. Ribeiro \& V.L.G.F. Lima. 1979. Germinação de sementes de algumas espécies arbóreas nativas do Cerrado. Rev. Bras. Sem. 1: 9-12 (also available on-line: www.abrates.org.br/revista/artigos/1979/v1n2/artigo01.pdf).

Mendes-Rodrigues, C., R. Carmo-Oliveira, S. Talavera, M. Arista, P.L. Ortiz \& P.E. Oliveira. 2005. Polyembryony and apomixis in Eriotheca pubescens (Malvaceae - Bombacoideae). Plant Biol. 7: 533-540.

Mendes-Rodrigues, C., F.P. de Araújo, C. Barbosa-Souza, V. Barbosa-Souza, M.A. Ranal, D.G. de Santana \& P.E. Oliveira. 2010. Multiple dormancy and maternal effect on Miconia ferruginata DC. (Melastomataceae) seed germination, Serra de Caldas Novas, Goiás, Brazil. Rev. Bras. Bot. 33: 93-105 (also available on-line: www.scielo.br/pdf/rbb/v33n1/09.pdf).

Miquel, S. 1987. Morphologie fonctionnele de plantules d'espèces forestières du Gabon. Bull. Mus. Hist. Nat. 9: 101-121.

Moreira, A.G. \& C.A. Klink. 2000. Biomass allocation and growth of tree seedlings from two contrasting Brazilian savannas. Ecotropicos 13: 43-51.

Oliveira, P.E.A.M. 2008. Fenologia e biologia reprodutiva de espécies de Cerrado, p. 273-290. In S.M. Sano, S.P. de Almeida \& J.F. Ribeiro (eds.). Cerrado: ecologia e flora. Embrapa Informação Tecnológica, Brasília, Brasil.
Oliveira, P.E.A.M. \& J.C.S. Silva. 1993. Reproductive biology of two species of Kielmeyera (Guttiferae) in the Cerrados of Central Brazil. J. Trop. Ecol. 9: 67.

Pedroso, S.G. \& V.P. Varela. 1995. Efeito do sombreamento no crescimento de mudas de sumaúma (Ceiba pentandra (L.) Gaertn). Rev. Bras. Sem. 17: 47-51 (also available on-line: www.abrates.org.br/revista/ artigos/1995/v17n1/artigo09.pdf).

Pereira, R.S., D.G. Santana \& M.A. Ranal. 2009. Emergência de plântulas oriundas de sementes recémcolhidas e armazenadas de Copaifera langsdorffii Desf. (Caesalpinioideae), Triângulo Mineiro, Brasil. R. Árvore 33: 643-652 (also available on-line: www. scielo.br/pdf/rarv/v33n4/v33n4a07.pdf).

Pinto, A.M., M.T. Inoue \& A.C. Nogueira. 2004. Conservation and vigour of balsawood seeds (Ochroma pyramidale). Acta Amazonica 34: 233-236 (also available on-line: www.scielo.br/pdf/aa/v34n2/v34n2a10.pdf).

Primack, R.B. 1980. Variation in the phenology of naturalpopulations of montane shrubs in New-Zealand. $\mathrm{J}$. Ecol. 68: 849-862.

Ranal, M.A. \& D.G. Santana. 2006. How and why to measure the germination process? Rev. Bras. Bot. 29: 1-11 (also available on-line: www.scielo.br/pdf/rbb/ v29n1/a02v29n1.pdf ).

Ranal, M.A., D.G. Santana, W.R. Ferreira \& C. MendesRodrigues. 2009. Calculating germination measurements and organizing spreadsheets. Rev. Bras. Bot. 32: 849-855 (also available on line: www.scielo.br/ pdf/rbb/v32n4/a22v32n4.pdf).

Ranal, M.A., D.G. Santana \& I. Schiavini. 2010. Are there germination patterns for cerrado species?, p. 106-159. In K. Del-Claro, P.S. Oliveira, V. RicoGray, A.A.A. Barbosa, A. Bonet, F.R. Scarno, F.J.M. Garzón, M.V. Sampaio, M.R. Morris, N. Ramirez, O. Marçal Júnior, R.H.F. Macedo, R.J. Marquis, L. Coelho, R.P. Martins, S.C. Rodrigues \& U. Luttge (eds.). Encyclopedia of life support systems. Tropical biology and conservation management, savannah ecosystems, UNESCO/EOLSS. Encyclopedia of life support systems, Oxford, England (also available on line: www.eolss.net).

Ressel, K., F.A.G. Guilherme, I. Schiavini \& P.E. Oliveira. 2004. Functional morphology and ecology of tree species seedlings of the Ecological Station of Panga, Uberlândia, Minas Gerais. Rev. Bras. Bot. 27: 311323 (also available on-line: www.scielo.br/pdf/rbb/ v27n2/v27n2a10.pdf). 
Ribeiro, J.F. \& B.M.T. Walter. 1998. Fitofisionomias do bioma cerrado, p. 89-166. In S.M. Sano \& S.P. Almeida (eds.). Cerrado: ambiente e flora. Embrapa Planaltina, Brasília, Brasília, Brasil.

Ronquim, C.C., C.H.B.A. Prado \& N.F. Paula. 2003. Growth and photosynthetic capacity in two woody species of cerrado vegetation under different radiation availability. Braz. Arch. Biol. Technol. 46: 243-252.

Rosa, R., S.C. Lima \& W.L. Assunção. 1991. Abordagem preliminar das condições climáticas de Uberlândia, MG. Soc. Nat. 3: 91-108.

Sánchez, O.S. \& C.H. Zepeda. 2004. Estudio morfológico de plántulas de la familia Bombacaceae en Quintana Roo, México. Foresta Veracruzana 6: 1-6 (also available on-line: redalyc.uaemex.mx/redalyc/src/inicio/ ArtPdfRed.jsp?iCve=49760201).

Sautu, A., J.M. Baskin, C.C. Baskin \& R. Condit. 2006. Studies on the seed biology of 100 native species of trees in a seasonal moist tropical forest, Panama, Central America. For. Ecol. Manag. 234: 245-263.

Scalon, S.P.Q., R.M. Mussury, M.R. Rigoni \& H.S. Filho. 2003. Initial growth of Bombacopsis glabra (Pasq.) A. Robyns seedlings under shading conditions. R. Árvore 27: 753-758 (also available on-line: www. scielo.br/pdf/rarv/v27n6/a01v27n6.pdf).

Silva Júnior, M.C., G.C. Santos, P.E. Nogueira, C.B.R. Munhoz \& A.E. Ramos. 2005. 100 Árvores do Cerrado: guia de campo. Rede de Sementes do Cerrado, Brasília, Brasília, Brasil.

Silva, L.A. \& A. Scariot. 2004. Arboreal community of a seasonal deciduous forest on limestone outcrop in São Domingos-Goiás, Parana river Basin, Brazil. R. Árvore 28: 61-67 (also available on-line: www.scielo. br/pdf/rarv/v28n1/a08v28n1.pdf).
Sokal, R.R. \& F.J. Rohlf. 1995. Biometry the principles and practice of statistics in biological research. Freeman, New York, USA.

Souza, R.P. \& I.F.M. Válio. 2001. Seed size, seed germination, and seedling survival of Brazilian tropical tree species differing in successional status. Biotropica 33: 447-457.

Souza-Silva, J.C., J.F. Ribeiro, C.E.L. Fonseca \& N.B. Antunes. 2001. Germinação de sementes e emergência de plântulas de espécies arbóreas e arbustivas que ocorrem em Matas de Galeria, p. 379-422. In J.F. Ribeiro, C.E.L. Fonseca \& J.C. Sousa-Silva (eds.). Cerrado: caracterização e recuperação de Matas de Galeria. Embrapa Cerrados, Brasília, Brasília, Brasil.

Vazquez-Yanes, C. 1974. Studies on the germination of seeds of Ochroma lagopus Swartz. Turrialba 21: 176-179.

Vieira, D.L.M., V.V. de Lima, A.C. Sevilha \& A. Scariot. 2008. Consequences of dry-season seed dispersal on seedling establishment of dry forest trees: Should we store seeds until the rains? Forest Ecol. Manag. 256: 471-481.

Zamith, L.R. \& F.R. Scarano. 2004. Seedling production of Restinga species of Rio de Janeiro municipality, RJ, Brazil. Acta Bot. Bras. 18: 161-176 (also available on-line: www.scielo.br/pdf/abb/v18n1/v18n1a14.pdf).

Zamora-Cornelio, L.F., S. Ochoa-Gaona, G.V. Simón, J.C. Albores \& B.H.J. de Jong. 2010. Germinación de semillas y clave para la identificación de plántulas de seis especies arbóreas nativas de humedales del sureste de México. Rev. Biol. Trop. 58: 717-732 (also available on-line: www.ots.ac.cr/tropiweb/attachments/ volumes/vol58-2/15-Zamora-Germinacion.pdf).

Wittmann, A., M.T.F. Piedade, P. Parolin \& F. Wittmann. 2007. Germination in four low-várzea tree species of Central Amazonia. Aquat. Bot. 86: 197-203. 
